\title{
AKAR TEOLOGIS ETOS KERJA JAMAAH TABLIGH Studi Kasus Komunitas Jamaah Tabligh Desa Temboro Kecamatan Karas Magetan
}

\author{
Ahmad Munir
}

\section{Abstrak:}

Salah satu janji agama adalah kebahagiaan bagi pengikutnya. Janji tersebut diterjemahkan sesuai dengan mindstreem masing-masing. Salah satunya adalah Jamaah Tabligh. Jamaah Tabligh menyatakan dirinya sebagai komunitas yang netral dalam bermadzhab, ber-ormas, dan berpolitik, tetapi dalam bingkai ahl al-sunnah wa aljamâ'ah. Mereka lebih menonjolkan aktivitas keberagamaannya secara riil melahui praktik dakwah dengan mengedepankan akhlaq. Menurut Jamaah Tabligh tujuan hidup adalah untuk beribadah, sebagai khalifah, dan untuk berdakwah. Realitas di lapangan menunjukkan bahwa Jamaah Tabligh memiliki etos kerja yang kuat dan ulet. Berdasarkan hal tersebut dirumuskan pertanyaan, bagaimana pandangan mereka terhadap kerja, ikhtiyar, dan tawakkal serta faktor-faktor yang melingkupinya. Pertanyaan tersebut dijawab dengan menggunakan logika induktif dengan menggunakan pendekatan kualitatif melahui analisis dan pemaknaan data lapangan yang telah diorganisir dengan sistematis untuk menemukan makna yang terdalam (deep-meaning) di balik realitas yang ada.

Hasil penelitian menunjukkan bahwa pola hidup Jamaah Tabligh didasarkan pada pemahaman konsep keagamaan yang dipegangi, yaitu enam sifat shahabat. Dari pemahaman tersebut, mereka berkeyakinan bahwa rizkidan keperluan hidup telah ditentukan Allah. Tetapi manusia wajib untuk mencari dan mengupayakan. Mereka memandang materi sebagai bagian yang tak terpisahkan dalam kehidupan, tetapi bukan menjadi tujuan hidup. Dari konsep pemahaman tersebut sekaligus menjadi dasar dalam berinteraksi dan berakulturasi dengan suasana yang baru. Akhimya proses yang dilakukan dapat dimanfaatkan dan membentuk iklim kompetisi yang sehat dan berakhir dengan kemakmuran dan keharmonian kehidupan.

Kata kunci: Etos kerja, Tawakkal, Ikhtiyar. 


\section{PENDAHULUAN}

Salah satu misi agama adalah menawarkan janji kebahagiaan bagi pengikutnya, baik secara lahir maupun batin. Janji mulia agama tersebut, dipahami dan diterjemahkan oleh pengikut agama sesuai dengan mindstreem masing-masing kelompok. Munculnya berbagai komunitas umat beragama sesungguhnya adalah untuk menerjemahkan janji agama yang diyakininya. ${ }^{1}$ Jamaah Tabligh didirikan oleh Maulana Muhammad Ilyas. Ia lahir pada tahun 1303 H/1885M, di Kandhla India adalah salah satu komunitas yang menawarkan cara untuk mencapai kebahagiaan. ${ }^{2}$

Jamaah Tabligh ini menyatakan dirinya sebagai komunitas yang netral, baik dari segi madzhab fiqih dalam menjalankan praktik keagamaan, ormas, dan politik. Hanya saja dalam berakidah, komunitas Jamaah tablih menyatakan dirinya sebagai kelompok ahl al-sunnah wa aljamâ'ah. ${ }^{3}$ Jamaah Tabligh lebih menonjolkan aktivitas keberagamaannya secara riil, yaitu melalui praktik dan upaya untuk mempengaruhi orang lain untuk melakukan praktik keagamaan, khususnya shalat Jamaah sebagaimana yang dia lakukan yang dikenal dengan istilah dakwah. Salah satu akhlaq yang ditekankan Jamaah Tabligh adalah untuk menghormati keberagaman paham dalam melaksanakan ibadah dalam bingkai menjalankan syari'at. ${ }^{4}$

Ada beberapa prinsip dalam berdakwah yang diajarkan oleh Jamaah Tabligh, di antaranya adalah; 1). Dalam berdakwah dengan cara kasar dan melakukan kekerasan, apalagi memaksa. 2). Awal dakwah yang dilakukan adalah mengajak orang lain untuk menjalankan shalat berjamaah. 3). Tempat yang paling mulia adalah masjid. 4). Tidak ada aktivitas dalam kehidupan yang lebih mulia dari berdakwah. Jamaah Tabligh mendoktrinkan bahwa setiap muslim harus memahami dua hal yaitu maksud hidup dan keperluan hidup. ${ }^{5}$ Maksud dan tujuan

${ }^{1}$ Budhy Munawar Rachman (ed), Kontekstualisasi Doktrin Islam dalam Sejarah (Jakarta: Paramadina, 1995), 103.

${ }^{2}$ Ali Nadwi, Riwayat Hidup dan Usaha Dakwah Maulana M. Ilyas, terj: Masrokhan A. (Yogyakarta: Ash-Shaff, 1999), 23.

${ }^{3}$ Ali Jabir, bin Husein bin Muhsin, Membentuk Jama'atul Muslimin (Jakarta: Gema Insani Press, 1998), 38.

${ }^{4}$ Darussalam dkk, Model Dakwah Jama'ah Tabligh (Salatiga: STAIN Salatiga Press, 2011), 28.

${ }^{5}$ Abdurrahman Ahmad As-Sirbuny, Mudzakarah Masturat (Cirebon: Pustaka Nabawi, 2009), 4. 
hidup untuk tiga hal yaitu untuk beribadah, ${ }^{6}$ sebagai khalifah ${ }^{7}$, dan untuk berdakwah atau penerus risalah. ${ }^{8}$ Sementara keperluan hidup dirumuskan dalam lima hal, yaitu makan minum, rumah, kendaraan, pakaian, dan pernikahan. Kelima hal ini harus diorientasikan pada tujuan hidup. ${ }^{9}$

Berdasarkan prinsip-prinsip tersebut, terkesan bahwa Jamaah Tabligh tidak memikirkan dan konsen pada bidang ekonomi baik secara mikro maupun makro. Padahal aktivitas dakwah dan pengabdian keagamaannya dilakukan secara mandiri dan tidak mengantungkan kepada pihak lain. Realitas di lapangan, Jamaah Tabligh ternyata memiliki tardisi dan etos kerja yang tinggi, kuat, dan ulet. Etos kerja tersebut ditandai dengan usaha yang dilakukan oleh masyarakat sesuai dengan keahlian dan bakat masing-masing. Dalam melakukan aktivitas ekonomi, Jamaah Tabligh tidak terlalu memikirkan masalah status pekerjaan, yang terpenting dapat mendatangkan rizki, manfaat, dan halal serta mendapat ridla Allah. ${ }^{10}$

Realitas tersebut sepintas bertolak belakang dengan konsep dan doktrin ajaran. Diduga ada doktrin dan prinsip ajaran lain yang dipegangi oleh anggota Jamaah Tabligh, yang tidak diketahui oleh pihak lain secara terbuka. Peneliti ini akan mengungkap doktrin dan paham keagamaan yang diajarkan dan dipegangi oleh Jamaah Tabligh, khususnya yang berkaitan dengan ajaran atau doktrin tentang etos kerja dan semangat dalam mencari sumber kehidupan.

\section{PEMBAHASAN}

\section{Konsep Keagamaan Jamaah Tabligh Dan Profil Desa Temboro} 1. Keadaan Penduduk

Desa Temboro berdasarkan letaknya berbatasan langsung dengan beberapa desa disekitarnya. Di sebelah utara berbatasan dengan desa Temenggungan dan Desa Karas, bagian selatan berbatasan dengan desa Kembangan dan Desa Kedungguwo, bagian timur berbatasan dengan desa Temenggungan dan Desa Tanjung Sepreh dan bagian barat berbatasan dengan desa Taji. Luas wilayah desa Temboro

\footnotetext{
${ }^{6}$ Tujuan ini didasarkan Q.S. Al-Dzâriyât: 56.

${ }^{7}$ Tujuan ini didasarkan Q.S. Al-Baqarah: 30.

${ }^{8}$ Tujuan ini didasarkan Q.S. Ali 'Imrân: 110.

${ }^{9}$ Abdurrahman Ahmad As-Sirbuny, Mudzakarah..., 4.

${ }^{10}$ Tokoh Jamaah Tabligh Temboro, Wawancara.
} 
adalah 517.320 ha. Desa Temboro terdiri dari empat Dusun yang dipimpin oleh seorang Kamituwo, empat Rukun Warga (RW) dan 33 Rukun Tetangga (RT). Jarak desa Temboro ke pusat Kecamatan adalah 2 km sedangkan jarak dengan ibu kota Kabupaten adalah 12 $\mathrm{km}$.

Jumlah penduduk desa Temboro per tahun 2017 adalah 7879 jiwa. Terdiri dari 4085 laki-laki dan 3794 perempuan yang bernaung di bawah 1732 kepala keluarga (KK). Dari data tersebut, penduduk laki-laki lebih banyak dari perempuan dengan perbandingan $51.8 \%$ untuk laki laiki dan 48.2\% untuk perempuan. Di lihat dari jumlah kepala keluarga (KK), setiap kepala keluarga hanya membawahi 4-5 orang. Dengan demikian, rata-rata keluarga desa Temboro termasuk keluarga kecil. ${ }^{11}$

Masyarakat desa Temboro termasuk masyarakat yang terbuka dari berbagai aspek. Baik dari aspek keagamaan, kultur, budaya, dan juga asal-usul penduduk. Hal ini dikarena desa Temboro memiliki potensi daya tarik migrasi masyarakat dengan berbagai budaya dan kulturnya yaitu keberadaan pesantren yang besar yang memiliki karakter tersendiri yaitu sebagai pusat gerakan Jamaah Tabligh. ${ }^{12}$ Kehadiran Jamaah Tabligh di desa Temboro memberikan banyak perubahan, mulai dari cara berpakaian, berbicara, dan pola kehidupan. Termasuk juga terjadinya asimilasi budaya dan asal penduduk dimana banyak pendatang yang akhirnya juga menetap di desa Temboro.

Pluralitas budaya dan kehidupan masyarakat di desa Temboro diluar dugaan yang sering dipesankan oleh teori sosial. Yaitu terjadinya problem sosial yang muncul akibat keterbukaan kehidupan masyarakat. Tetapi yang terjadi di desa Temboro adalah sebaliknya. Kehadiran para pendatang justru mambawa dampak positif bagi masyarakat desa Temboro, mulai dari aspek ekonomi, budaya, dan kemajuan sosial. Hal ini dikarena mereka datang ke desa Temboro dengan tujuan yang mulia, yaitu menuntut ilmu, berdakwah, membenahi moral, dan karakter diri. ${ }^{13}$

${ }^{11}$ Data diambil dari data dan dokumen di desa dan diambil dari situs resmi desa Temboro, diakses tanggal 20 September 2017.

${ }^{12}$ Hasil diskusi dengan K.H. Fajar Rahman, salah satu penggerak dakwah Jamaah Tabligh.

${ }^{13}$ Sekretaris desa Temboro, Wawancara. 


\section{Sumber Daya Manusia dan Kehidupan Sosial Keagamaan}

Desa Temboro memiliki aset sosial yang potensial, yaitu adanya pondok pesantren al-Fatah. Keberadaan pondok ini, tidak sekadar menyumbang bagi status sosial masyarakat, tetapi memiliki pengaruh dan daya magnit yang kuat terhadap masyarakat Temboro. Dengan berdirinya pesantren yang besar di desa Temboro, memberikan dampak yang signifikan bagi kehidupan sumber daya manusia desa Temboro. Menjadikan masyarakat desa Temboro sebagai masyarakat pembelajar, baik formal maupun informal. Pembelajaran formal terjadi di sekolah dengan peserta didik usia sekolah. Sementara pembelajaran informal dan non formal terjadi baik pada anak usia belajar maupun usia dewasa. Usia dewasa bergabung dalam majelis taklim dan halaqah-halaqah, baik di masjid mupun di mushalla. ${ }^{14}$

Ajaran Jamaah Tabligh tidak dapat dipisahkan dengan nafas dan paham sosial masyarakat Temboro. Ajaran shalat berjamaah, menghargai tamu, dan saling berbuat baik kepada sesama manusia menjadikan kehidupan masyarakat tentram, tertib, dan penuh keharmonian. ${ }^{15}$ Salah satu keunikan masyarakat Temboro dengan Jamaah Tabligh adalah terjadinya asimilasi budaya dan kehidupan yang signifikan dan harmoni. Ajaran Jamaah Tabligh diterima dan mewarnai kehidupan masyarakat desa Temboro. Ada beberapa ajaran yang menjadi ikon Jamaah Tabligh yang dipraktikan oleh masyarakat desa Temboro secara massif, yaitu cara berpakaian, taat cara pergaulan, dan kesantunan. Dari ketiga hal tersebut, akhirnya membentuk kultur kehidupan yang terpadu pada masyarakat desa Temboro. Yaitu antara kultur kehidupan sosial masyarakat dengan kultur kehidupan yang didasarkan pada ajaran agama. ${ }^{16}$

\section{Kehidupan Ekonomi.}

Jika dililaht dari perbandingan antara jumlah kepala keluarga (KK) yang berjumlah $1732 \mathrm{KK}$ dengan jumlah usaha ekonomi yang mencapai 234, maka hampir dipastikan setiap 7,5 KK memiliki satu usaha. Kondisi ini sangat baik sekali dilihat dari tingkat kesejahteraan masyarakat. Dengan demikian kondisi ekonomi masyarakat desa Temboro sangat produktif.

\footnotetext{
${ }^{14}$ Ibid.

${ }^{15} \mathrm{Ibid}$.

${ }^{16} \mathrm{KH}$. Mursyidin, Tokoh agamawan Desa Temboro, Wawancara.
} 
Dari data di atas, menunjukan bahwa etos ekonomi dan etos untuk membangun kehidupan bagi masyarakat desa Temboro adalah tinggi. Hal ini dibuktikan juga dengan jumlah pelajar yang juga tinggi. Ini juga menggambarkan adanya nadi ekonomi yang baik yang mampu menunjang elemen-elemen kehidupan yang lain. Ketika masyarakat mampu membiayai dan mengantarkan putra-putrinya ke dunia pendidikan, sebagai indikator bahwa masyarakat tersebut adalah masyarakat terpelajar dan masyarakat terpelajar sebanding lurus dengan masyarakat yang memiliki kesejahteraan.

\section{Pokok-Pokok Ajaran Jamaah Tabligh}

Asal usul gerakan Jamaah Tabligh berasal dari anak benua India, yang ini didirikan oleh Muhammad Ilyas al-Kandahlawy. Muhammad Ilyas lahir pada tahun $1303 \mathrm{H}$ di desa Kandahlah di kawasan Muzhafar Nagar, Utara Bangladesh India. Ia wafat pada tanggal 11 Rajab 1363 H. Istilah al-Kandahlawi berasal dari kata Kandahlah. Yaitu nama sebuah desa yang terletak di daerah Sahranfur. Sementara alDihlawi adalah nama lain dari Dihli (New Delhi) yang merupakan ibu kota India saat ini. Di negara inilah markas gerakan Jamaah Tabligh berada. Adapun al-Diyubandi adalah asal kata dari Diyuband yaitu lembaga pendidikan yang berbentuk madrasah terbesar bagi penganut madzhab Hanafi di semenanjung India. Sementara al-Jisyti merupakan penisbatan pada tarekat yang bernama al-Jisytisiyah yang didirikan oleh Mu'inuddin al-Jisyti. ${ }^{17}$

Muhammad Ilyas menerima pendidikan agama di Madrasah Islam Deoband India. Di sini dia belajar al-Quran, al-Hadits, Fiqh, dan ilmu Islam yang lain. Dia juga belajar hadist Jâmi' Shahîh alTurmuzdi dan Shahîh al-Bukhâri dari seorang alim yang bernama Mahmud Hasan. ${ }^{18}$ Kemudian melanjutkan belajar Kutub al-Sittah pada kakaknya sendiri yaitu Muhammad Yahya yang wafat pada tahun $1334 \mathrm{H}^{19}$

Muhammad Ilyas mendirikan gerakan Jamaah Tabligh untuk merealisasikan ajaran Islam secara riil dalam kehidupan

${ }^{17}$ Ahmad Syafi'i Mufid, Perkembangan Paham Keagamaan Transnasional Indonesia. (Jakarta: Kementrian Agama RI; Badan Litbang Dan Diklat Puslitbang Kehidupan Keagamaan, 2011), 147.

${ }^{18}$ An Nadwi, Sejarah Maulana Ilyas Menggerakkan Jamaah Tabligh, 14.

${ }^{19} \mathrm{Ibid}, 20$. 
sehari-hari. Oleh karenanya, tujuan utama pergerakan ini adalah untuk menyebarkan agama Islam dan menghidupkan sunnah Nabi. Disamping itu juga untuk membendung kristenisasi dan mengembalikan kaum Muslimin yang lepas ke dalam pangkuan Islam. ${ }^{20}$ Kondisi ini yang mendorong untuk berdakwah yang kemudian diwujudkannya dengan membentuk gerakan Jamaah Tabligh pada tahun 1926 Masehi. $^{21}$ Setelah Muhammad Ilyas menjalankan hajinya yang kedua, dia tiba di Kandahlawi pada tanggal 13 Rabi'ul Akhir 1345 H, bertepatan pada tanggal 25 September 1926, sebagai momentum pendirian Jamaah Tabligh.

Jamaah ini awalnya tidak mempunyai nama, cukup dengan sebutan Islam. Kata Jamaah Tabligh merupakan sebuah nama bagi mereka yang menyampaikan dakwah. Muhammad Ilyas mengatakan seandainya aku harus memberikan nama pada usaha ini, maka akan aku beri nama "gerakan iman". 22 Jamaah Tabligh resminya bukan merupakan kelompok atau ikatan, tapi gerakan muslim untuk menjadi muslim yang menjalankan agamanya, yang tidak memandang asal-usul mahdzab atau aliran pengikutnya. Dalam menjalankan misi dakwahnya, Jamaah Tabligh mendatangi masyarakat secara langsung, baik di perkotaan atau di pedesaan. Mereka mengajak masyarakat untuk menjalankan ajaran Islam secara maksimal dan merealisasikan sunnah-sunnah Nabi dalam kehidupan riil. ${ }^{23}$

\section{Figur-figur Sentral dan Literasi Jamaah Tabligh}

Suatu gerakan tidak dapat dilepaskan dari figur yang mensupport ideologi yang menggerakkannya. Ada beberapa tokoh yang menjadi figur yang menggerakkan Jamaah Tabligh yang terkenal antara lain: 1) Muhammad Ilyas, dia sebagai penggagas berdirinya Jamaah Tabligh. ${ }^{24}$ 2) Muhammad Yusuf yaitu putra Muhammad Ilyas, beliau menyusun kitab antara lain al-Muntakhab al-Hadîts dan buku khurûj fi Sabîlillâh menurut al-Quran dan al-Hadits yang dijadikan rujukan Jamaah

${ }^{20}$ An Nadwi, Sejarah Da'wah Dan Tabligh Maulana Ilyas Rah., 78.

${ }^{21}$ Ruhaiman, "Jama'ah Tabligh Surabaya 1984-2008 (Studi Sejarah dan Aktifitas Keagamaannya” (Skripsi IAIN Sunan Ampel Fakultas Usuludin, Surabaya, 2008), 25.

${ }^{22}$ Mulwi Ahmad Harun Al Rosyid, Meluruskan Kesalahpahaman terhadap Jaulah (Jamaah Tabligh) (Magetan: Pustaka Haromain, 2004), 21.

${ }^{23}$ Abdullah Qaf, Wawancara, Kupang, 19 Agustus 2015.

${ }^{24}$ An Nadwi, Sejarah Maulana Ilyas Menggerakkan Jamaah Tabligh, 7. 
Tabligh dalam berdakwah. ${ }^{25}$ 3) Istihyam al-Hasan, yang menggantikan MuhammadYusuf. 4) Zakariya al-Kandhalawi, keponakan Muhammad Ilyas. ${ }^{26}$ 5) Manzhur Nu'many, ia adalah seorang tokoh Jamaah Tabligh yang dekat dengan Muhammad Ilyas. 6) Abul Hasan Ali Nadwi, yang sering mendampingi Muhammad Ilyas. 7) Syekh Muhammad Sa'ad al-Kandhalawi, cucu Muhammad Yusuf.

Dalam menjalankan dakwah, Jamaah Tabligh mempunyai kitabkitab rujukan yang digunakan untuk pegangan dalam menyelesaikan berbagai masalah yang berkaitan dengan dakwah dan kehidupan. Kitab yang dijadikan rujukan di kalangan Jamaah Tabligh adalah kitab Tabligh al-Nishâb yang dikarang oleh Muhammad Zakaria al-Kandahlawi. Kitab ini sangat diagungkan bagi Jamaah Tabligh. Di samping itu ada beberapa kitab yang dijadikan rujukan bagi Jamaah Tabligh antara lain: 1) Kitabkitab Fadhîlah al-'Amal karya Maulana Zakaria. Di samping kitab ini, juga terdapat kitab-kitab fadhîlah al-'amal yang disusun secara tematik atau merupakan himpunan dari beberapa kitab, yaitu kitab Fadhîlah alShalât, Kitab fadhîlah al-Dzikir, Kitab fadhîlah al-Tablìgh, Kitab fadhîlah al-Quran, Kitab fadhîlah Ramadhân, Kitab fadhîlah al-Shadaqah, Kitab fadhîlah al-Hajj, Kitab fadhîlah al-Tijârah, Fadhilah Janggut, Kisah-Kisah Para Shahabat dan lain-lain. ${ }^{27}$ 2) Kitab Hayât al-Shahâbah karya Yusuf. 3) Kitab al-Hadits al-Muntakhabah karya Yusuf. Kitab ini merupakan himpunan hadist-hadist pilihan untuk enam sifat para sahabat. 4) Kitab Riyâdl al-Shâlihîn karya Imam Nawawi. 5) Kitab al-Targhib wa al-Tarhîb karya Hafizh al-Mundziri. 6) Kitab fadlâ'il al-Haji dan fadlâ'il shalawât karya Syaikul HadistMuhammadZakaria Kandhlawiyang diterjemahkan dalam bahasa Indonesia. Fadlâil al-Haji dibacakan menjelang musim haji. Kitab kitab tersebut memiliki nuansa doktrin pembentukan akhlak. Mulai dari ketaatan dalam berkelompok, semangat untuk mengamalkan dan melaksanakan suatu kebajikan, hingga sirah dan sejarah perjalanan shahabat.

\section{Pokok-Pokok Ajaran Jamaah Tabligh}

Dalam menyampaikan dakwah, Jamaah Tabligh mempunyai ajaran pokok yang dituangkan dalam enam prinsip doktrin yang menjadi

${ }^{25}$ Al Rosyid, Meluruskan Kesalahpahaman terhadap Jaulah (Jamaah Tabligh), 7.

${ }^{26} \mathrm{Al}$ Rosyid, Meluruskan Kesalahpahaman terhadap Jaulah (Jamaah Tabligh), 7.

${ }^{27} \mathrm{Ibid}, 22$. 
asas dakwahnya. Enam doktrin tersebut diambil dari sifat shahabat Nabi. Pokok ajaran ini bukan mendistorsi konsep Islam dan konsep risalah, tapi untuk memudahkan muslim untuk mengamalkan ajaran Islam. ${ }^{28}$ Adapun keenam sifat tersebut adalah:

a. Yakin Kepada Kalimah Thayyibah, yang disebut kalimah agung yaitu lâ ilâha illa Allah, Muhammad Rasûlullâh. Makna dari kalimat ini adalah bahwa semua makhluk tidak memiliki kekuatan apapun selain kekuatan dari Allah. Menyakini bahwa hanya Allah yang mengurus dan mengatur makhluk dan segala sifat-sifatnya (rubuiyah). ${ }^{29}$ Sedangkan makna kalimat Muhamad rasûlullâh bermakna mengakui bahwa satu-satunya jalan hidup untuk mendapatkan kejayaan dunia dan akhirat hanya dengan mengikuti rasulullah. ${ }^{30}$

b. Shalat khusŷ̀' wa al- khudlû. Setelah menyakini kalimat thayyibah, muslim harus menunaikan shalat dengan penuh kekhusu'an. Makna shalat khusyû' dan khudlû' adalah shalat dengan konsentrasi batin dan rendah diri dengan mengikuti cara yang dicontohkan oleh Rasulullah. Tujuannya adalah untuk membawa sifat-sifat ketaatan kepada Allah dalam shalat ke dalam kehidupan sehari-hari. Sedangkan cara mendapatkan shalat khusyû' wa al-Khudlû' adalah dengan mendakwahkan

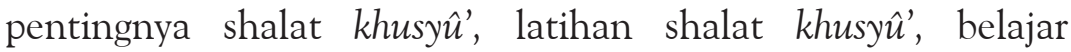
menyelesaikan masalah dengan shalat, dan berdo'a kepada Allah agar diberikan taufiq untuk mengerjakan shalat dengan khusy $\hat{u}^{\prime}{ }^{31}$

c. Ilmu dan Dzikir (Al-'Ilm Ma'a al-Dzikr) Ilmu dan dzikir suatu kesatuan yang tidak dapat dipisahkan. Orang yang berdzikir tanpa mengetahui ilmunya, bisa jadi akan melakukan dengan ngawur. Begitu juga dengan ilmu yang tidak diikuti dengan dzikir, diibaratkan berjalan tanpa arah dan tujuan. Ilmu untuk mengetahui perintah Allah dalam setiap suasana dan keadaan,

${ }^{28}$ Abdurrahman Ahmad As-Sirbuny, Mudzakarah Masturat (Cirebon: Pustaka Nabawi, 2009), 16.

${ }^{29}$ Maulana Manshur, Masturah: Usaha Dakwah di Kalangan Wanita (Bandung: Pustaka Ramadhan, 2007), 23-26.

${ }^{30}$ An Nadhr M. Ishaq Shahab, Khuruj fisabilillah: Sarana Tarbiyah Untuk Membentuk Sifat Imaniyah, terj. Abu Sayyid Akmal (Bandung: Pustaka Zaadul Ma'aad), 106.

${ }^{31}$ Mustofa Sayani, Mudzakarah Enam Sifat Para Sahabat RA. (Bandung: Pustaka, 2006), 12-13. 
sementara dzikir adalah untuk menghadirkan Allah dalam setiap perintah-Nya. Melaksanakan perintah Allah dalam setiap keadaan dengan menghadirkan keagungan Allah mengikuti cara Rasulullah. Ilmu dibagi menjadi dua yaitu ilmu fadlâ'il dan ilmu masâ'il. Ilmu fadlâ'il adalah ilmu yang membahas keutamaan keutamaan dalam beragama. Sedangkan ilmu masâ'il adalah ilmu yang membahas tentang hukum yang ditetapkan agama. ${ }^{32}$ Dalam berdakwah, Jamaah Tabligh lebih banyak mengkaji dan mendakwahkan ilmu fadlâ'il dari pada ilmu masâ'il. Karena ilmu fadlâ'il dinilai lebih aplikatif dan memberikan pengaruh yang riil dalam membina akhlaq muslim. Sementara ilmu masâ'il ketika diterima oleh mereka yang kurang mengusai diri dan akhlak, sering dijadikan sebagai ajang perpecahan. ${ }^{33}$

d. Memuliakan Ummat Islam (Ikrâm al-Muslimîn). Merepotkan orang lain hanya akan merusak amal. Tujuan memuliakan sesama muslim adalah agar kita dapat menyampaikan hak dan kewajiban kepada sesama muslim. Keharmonian komunikasi sesama adalah awal kesuksesan dakwah. Memuliakan sesama muslim adalah salah satu pintu yang mengantarkan kepada amal kebajikan. ${ }^{34}$

Sifat pertama, kedua, dan ketiga tidak boleh berdiri sendirisendiri. Diawali kesamaan keyakinan, baik terhadap sumber kebenaran dan kebenaran pembawanya. Kemudian menjalankan syari'at yang disampaikan, yang diikuti dengan ilmu maka diharapkan muncul rasa simpatik dan empatik terhadap sesama muslim. Sebelum menjalankan sifat Ikrâm al-Muslimîn, terlebih dahulu harus menghindarkan diri dari hal-hal yang mengundang perpecahan. Ketika ada sesuatu yang mengundang perpecahan, sulit untuk menghadirkan sifat Ikrâm al-Muslimîni. Karena perpecahan didorong oleh nafsu untuk mencari kemenangan dan nafsu kemenangan hanya akan memuliakan dirinya dengan merendahkan orang lain. ${ }^{35}$

${ }^{32}$ Maulana Yusuf al-Kandhalawi, Enam Sifat Para Sahabat dan Amalan Nurani (Bandung: Pustaka Ramadhan, 2008), 18.

${ }^{33}$ Wawancara, 11 September 2017.

${ }^{34}$ Maulana Manshur, Masturah: Usaha Dakwah di Kalangan Wanita (Bandung: Pustaka Ramadhan, 2007), 35.

${ }^{35}$ Wawancara, 11 September 2017. 
e. Memperbaiki Niat (Tahsin al-Niyyah). Niat yang tertata dan direncanakan dikenal dengan sikap Ikhlas. Ikhlas berarti meluruskan, memperbaiki, dan membersihkan niat dalam hati dari segala hal yang bukan ditujukan kepada Allah. Ikhlas adalah suatu rahasia antara hamba dengan Tuhannya yang tidak diketahui oleh siapapun. Ikhlas merupakan ruh dari semua amal perbuatan yang kita lakukan. ${ }^{36}$ Ketulusan niat menjadikan para pekerja dakwah rela untuk mengorbankan waktu, tenaga, dan materi untuk berdakwah. Kerja dakwah membutuhkan banyak pengorbanan. Waktu yang seharusnya dapat dugunakan untuk bekerja dan hal lain dalam aktivitas kehidupan, semua harus berhenti hanya digunakan untuk kerja dakwah. Materi yang sesungguhnya dapat digunakan untuk bersenang-senang dalam kehidupan, harus disisihkan untuk modal dan bekal dalam berdakwah. ${ }^{37}$

f. Khurûj fî Sabîlillâh. Tujuannya adalah untuk memperbaiki diri. Yaitu menggunakan diri, harta, dan waktu seperti yang diperintahkan Allah. Menghidupkan agama pada diri sendiri dan orang lain dengan menggunakan harta dan diri mereka. ${ }^{38}$ Sebelum berangkat khurûj terdapat pembekalan yang dilakukan oleh pimpinannya, antara lain: 1) Bayân Hidâyah, yang dilakukan sebelum pemberangkatan Jamaah ke tempat pengiriman da'i agar si da'i paham dan mengerti apa apa yang harus dilakukan ketika sampai tujuan. 2) Musyawarah tentang keperluan yang perlu dipersiapkan dalam khurûj fî Sabîlillâh, dan mudzâkarah tentang adab-adab safar. 3) Bayân Wabsi, yang dilakukan setelah pulang dari berdakwah kepada penggurus markas. 4) Bayân Karghozari, yang dilakukan setelah kembali dari khurûj tentang kondisi Islam di daerah yang telah disinggahi.

\section{Pandangan Jamaah Tabligh tentang Kerja \\ 1. Konsep tentang Kerja}

Al-Qur'an memandang dunia bersifat teosentris, artinya segala sesuatu bersentral pada citra Sang Pencipta. Citra tersebut harus

${ }^{36}$ Abdurrahman Ahmad As-Sirbuny, Mudzakarah Masturat (Cirebon: Pustaka Nabawi, 2009), 27.

${ }^{37}$ Wawancara, 11 September 2017.

${ }^{38}$ Furqon Ahmad Anshari, Pedoman BerTabligh Bagi Umat Islam (Yogyakarta: AshShaff, 2013),128. 
terrefleksi secara utuh dalam kehidupan manusia. Voluntarisme rasional memandang bahwa suatu tindakan dikatakan etis jika tindakan tersebut berasal dari produk pilihan sadar dalam situasi bebas, bukan dalam keterpaksaan. Dengan demikian pertanggungjawaban secara etis dapat dilakukan jika suatu perbuatan dilakukan dalam keadaan sadar dan dalam bingkai kebebasan. Semakin luas wilayah kebebasan dalam berbuat, maka semakin berat pertanggung jawaban moralnya. ${ }^{39}$ Dorongan Islam kepada ummat muslim untuk menjalin hubungan dengan sesamanya di dalam kehidupan, tidaklah harus mengesampingkan monoteisme mutlak. Tetapi melewatinya lebih dan memberikan kepada manusia keagungan yang sebenarnya dan memungkinkan untuk mengembangkan kebajikannya. Islam menganjurkan manusia mengutamakan hal-hal yang bersifat spiritual dan mengambil faedah secara wajar dari kekayaan yang diberikan Allah. ${ }^{40}$ Islam telah menetapkan nilai pribadi manusia dan menentukan batas-batasnya serta menetapkan kewajiban secara proporsional demi keseimbangan antara pribadi dan masyarakat. ${ }^{41}$

Jamah Tabligh memandang bahwa kerja adalah suatu keniscayaan. Kerja yang dianggap bagian dari syari'at adalah kerja yang didasarkan pada orientasi tauhid. Salah satu orientasi tauhid dalam bekerja adalah bahwa bekerja tidak boleh bertentangan dengan filosofi tauhid. Salah satunya adalah al-nafyu wa al-itsbât. Dalam konsep al-nafyu wa al-itsbât, manusia dituntut untuk menafikan semua yang ada dihadapan mata, semua makhluk, bahwa semua itu adalah semu. Manusia dituntut untuk menetapkan yang ghaib, bahwa yang ghaib itu yang pasti.

Enam sifat shahabat yang dijadikan konsep pokok ajaran Jamaah Tabligh, hal penting yang berkaitan dengan konsep kerja adalah (1) sifat yang pertama yang berkaitan dengan keyakinan terhadap kalimah thayyibah, (2) ikrâm al-muslimîn, dan (3) dakwah wa latablìgh. Keyakinan terhadap kalimah thayyibah menjadi dasar keyakinan terhadap kerja. Konsep nafyu dan itsbât dalam kalimah thayyibah tersebut menjadikan manusia agar menafikan semua yang

${ }^{39}$ Madjid Fakhri, Etika Dalam Islam, Terj. Zakiyuddin Baidhawy (Yogyakarta: Pustaka Pelajar, 1996), 49.

${ }^{40} \mathrm{Al}$-Qashash/28: 77.

${ }^{41}$ Marcel A. Boisard, Humanisme dalam Islam, Terj. M.Rasjidi (Jakarta: Bulan Bintang, 1980), 89 . 
nampak. Karena semua yang nampak ini berawal dari ketiadaan dan akan berakhir dengan ketiadaan juga. Sementara mengitsbatkan yang tidak nampak, hakikatnya adalah menguatkan sesuatu yang haq, yaitu Allah sebagai pencipta, pengada, dan pemelihara semua makhluk. Ketika manusia menetapkan yang tidak tetap, bisa jadi ia akan mendapatkan sesuatu itu dan bisa jadi tidak mendapat. Ketika mendapat sesuatu tersebut, bisa jadi ia sombong dan lupa dengan yang membuat dan memiliki (Allah). Dan jika tidak mendapatkannya, bisa jadi ia akan kufur, tidak sekadar terhadap yang dia cari, tetapi juga kufur terhadap yang mencipta sesuatu yang dia cari.

Prinsip ikrâm al-Muslimin, mendorong manusia untuk memiliki bekal materi untuk terlaksananya prinsip tersebut. Jika manusia tidak memiliki materi, maka susah untuk memuliakan atau memudahkan orang Islam. Lebih dari itu justru akan selalu menyusahkan orang Islam yang lain. Prinsip al-Dakwah wa al-tablîgh bahwa hidup adalah untuk dakwah yang merupakan amalan paling mulia dalam upaya untuk menyampaikan konsep risalah, baik untuk diri sendiri maupun kepada orang lain.

\section{Konsep tentang Etika Bekerja}

Al-Qur'an dan al-Sunnah telah menyuruh manusia untuk berusaha dalam pemenuhan tanggung jawab. Perintah tersebut tidak sekadar perintah bekerja yang hanya menghasilkan materi, akan tetapi untuk mencari sebuah nilai dari apa yang diusahakan yang akan memberi manfaat baik bagi diri yang bersangkutan maupun bagi orang lain. Dalam pandangan al-Qur'an, kerja hanya merupakan salah satu bentuk ikhtiyâr yang harus dilakukan oleh manusia. Al-Qur'an tidak menafikan usaha manusia, tetapi usaha manusia bukanlah segalagala untuk menentukan hasil yang diinginkan. Faktor alam yang melingkungi yang di luar kendali dan kemampuan manusia juga memiliki andil.

Orientasi yang dituju dari ikhtiyâr bukan kerja yang kapitalistik murni yang hanya berorientasi pada pertambahan nilai dari sebuah barang. Dari pengidolaan kerja yang bermental materialistik, akhirnya menjadikan manusia asing dari dirinya sendiri dan orang lain. Dengan demikian manusia menjadi terbelenggu dan terpenjara oleh kebutuhan dan hasrat biologis murni. Pekerjaan bukan 
mengembangkan orientasi kehidupan, melainkan memenjara dan mengasingkan manusia baik dari dirinya sendiri maupun orang lain. ${ }^{42}$ Al-Qur'an menghendaki agar kerja manusia diorientasikan pada nilai-nilai suci, bukan sekadar materi secara unsich. Nilai suci dari materi ditentukan oleh fungsi dan kegunaannya untuk kemaslahatan dalam memenuhi hajat hidup manusia.

Berangkat dari konsep al-nafyu wa al-itsbât, Jamaah Tabligh memandang bahwa kerja sebagai aktivitas basyariah dan kemakhlukan, dipandang sebagai sesuatu hal yang wajar. Tetapi yang penting adalah kesadaran niat dan hati manusia terhadap apa yang ia lakukan, yaitu segala sesuatunya harus diatasnamakan untuk mencari ridla ilahi. Dengan kekuasaan ilahi, hal yang mustahil menurut manusia bisa terjadi. Dengan kekuasaan ilahi pula hal yang dipandang mesti oleh manusia, bisa nihil.

Oleh karenanya, dalam bekerja hal penting harus diperhatikan adalah bukan masalah proses dan mekanisasi. Akan tetapi nilai nilai etis dalam bekerja agar jangan sampai melanggar syari'at yang ditentukan oleh Allah. Ketentuan Allah harus di atas pekerjaan. Ketika ada benturan waktu antara kerja dan seruan Allah, maka seruan Allah harus didahulukan dari kerja materi. Tidak ada alasan atas nama kerja dengan meninggalkan dan melanggar syari'at. Tidak dapat dibenarkan, hanya atas nama alasan kerja, sehingga tidak mengindahkan perintah menutup aurat. ${ }^{43}$

Al-Qur'an memberikan orientasi melalui piranti-piranti dalam mencari materi yang harus dipatuhi oleh manusia. Orientasi tersebut untuk memberikan keseimbangan usaha manusia dalam mendapatkan materi agar sesuai dengan harapan yang dicita-citakan sebagai khalifah di bumi. Keseimbangan tersebut baik terhadap Tuhan, terhadap dirinya sendiri, terhadap lingkungan, maupun terhadap sesama manusia. Piranti-piranti tersebut di antaranya adalah; 1) Melarang bertransaksi secara illegal, 2) Penyempurnaan Kontrak (timbangan/takaran) dalam transaksi, 3) Larangan bersistem ribâ, dan 4) Menekankan tanggung jawab (amânah). Rasa

${ }^{42}$ Franz Magnis-Suseno, Pemikiran Karl Marx Dari Sosialisme Utopis ke Perselisihan Revisionisme (Jakarta: Gramedia, 1999), h. 95. M. Dawam Rahardjo, Ensiklopedi AlQur'an (Jakarta: Paraamadina, 2002), 575, Erich Fromm, Konsep Manusia Menurut Marx (Yogyakarta: Pustaka Pelajar, 2002), 58.

${ }^{43}$ Wawancara, 12 September 2017. 
tanggung jawab terhadap hasil pekerjaan, didorong oleh kepercayaan bahwa mengkhianati orang yang memberi amanat akan menjadikan hidupnya kesusahan tanpa berkesudahan. Pengkhianatan dalam bekerja ibarat setetes racun yang akan meracuni susu sebelanga. Ketidakjujuran atau akibat dari tidak tanggung jawab dari produk kerja, akan menjadikan orang lain tidak percaya terhadap prosesnya, dan hingga tidak percaya pada dirinya. Hasil akhirnya orang lain sama mencabut amanat dan tanggung jawab yang telah diberikan kepadanya. Hingga akhirnya orang tersebut tidak memiliki tanggung jawab apa-apa. Akibatnya dia tidak lagi dipekerjakan. Pada akhirnya rizki Allah juga terputus akibat dari sikap dan rasa tidak tanggung jawab. ${ }^{44}$

\section{Perspektif Jamaah Tabligh tentang Tawakkal dan Ikhtiyar}

\section{Konsep Ikhtiyar dalam Kehidupan}

Tawakkal dan ikhtiyar, seperti dua sisi mata uang yang tidak bisa dipisahkan. Tidak mudah untuk memahami konsep tawakkal dan ikhtiyar dalam kehidupan. Karena manusia memiliki dua sisi sifat, yaitu sifat ilâhiyyah dan sifat nâsûtiyyah. Sifat ilâhiyyah sering muncul ketika manusia mengalami dan menghadapi problem kehidupan yang berat untuk dihadapi. Sifat nâsûtiyyah muncul ketika manusia sedang dalam kondisi yang sattle, aman, dan nyaman. Sifat ilâhiyyah dan sifat nâsûtiyyah idealnya menjadi kontrol bagi manusia dalam kehidupannya. Kapan pun dan di mana pun dan dalam keadaan apa pun. Ketika manusia merasa kenyamanan dan kesenangan, bahwa itu adalah karunia ilahi yang dianugerahkan kepadanya. Jika sifat ilâhiyyah dan sifat nâsûtiyyah dapat termenej dengan baik dalam kehidupan, maka manusia akan merasakan bahwa kehidupan ini adalah anugerah yang selalu untuk disyukuri.

Didasarkan pada prinsip ajaran Jamaah Tabligh yaitu keyakinan akan kalimah thayyibah, ketika manusia mampu menafikan alam materi yang sedang dia gumuli, maka dia akan mampu menerima apa pun yang terjadi dalam kehidupan. Kekecewaan dan sikap kufur manusia, disebabkan dia tidak mampu menafikan dunia materi. Dalam waktu yang sama, dia juga tidak mampu menetapkan sesuatu yang pasti dan abadi. Ketika manusia mengitsbatkan yang abadi,

${ }^{44}$ Wawancara, 15 September 2017.

Kodifikasia, Volume 11 No. 1 Tahun 2017 
maka ketika dia gagal dalam dunia materi, maka dia sadar bahwa hal itu bukan apa apa. Kerena sesungguhnya dunia materi itu adalah sirna. ${ }^{45}$

\section{Ikhtiyâr dan Taqdir dalam Kehidupan}

Muslim sunni menjadikan kepercayaan kepada takdir ilahi sebagai rukun iman yang keenam. Meskipun kalau kita jujur bahwa poin ini tidak termaktub dalam al-Qur'an. Al-Qur'an hanya menyebut lima pilar sebagai rukun iman, sebagaimana yang disebut dalam surat alNisâ'/4: 136. Mayoritas muslim mempercayai takdir ilahi. Hanya saja mereka berbeda-beda dalam memahaminya. Salah satu pemahaman yang fatal adalah pikiran yang menyalahkan takdir itu sendiri ketika manusia merasakan sesuatu yang mengganggu keinginannya. ${ }^{46}$

Kata taqdîr berasal dari bahasa Arab qaddara yang berasal dari kata qadara, yang memeliki beberapa padanan makna yaitu mengukur, memberi kadar, atau ukuran. ${ }^{47}$ Dari makna ini memberikan isyarat bahwa suatu ketetapan itu selazimnya adalah ideal. Karena jika tidak ditetapkan maka ada terjadi kesenjangan, apakah ketidaksesuaian dari aspek kapasitas karena sedikit atau karena kelebihan. Di luar taqdir berarti terjadi kondisi ekstrem, baik karena ketidakcukupan maupun karena kelebihan.

Setiap manusia memiliki takdir yang berbeda antara satu dengan yang lain. Manusia hidup dalam lingkaran takdir yang tidak dapat menghindarnya yang dikenal dengan hukum-hukum Allah (sunnatullah) yang beraneka ragam kadar dan ukurannya. Dalam menerima takdir, manusia harus menyadari bahwa hukum atau ketentuan ilahi itu banyak. Manusia diberi kebebasan untuk memilihnya. Maka ketika seseorang berpindah dari satu pilihan menuju pilihan yang lain, sesunguhnya itu pun dalam wilayah takdir. Keluar dari tempat yang terinveksi wabah suatu penyakit, ke daerah lain yang dipandang aman, adalah sama halnya berpindah dari satu takdir ke takdir yang lain. Hal ini dibenarkan oleh Islam. ${ }^{48}$

${ }^{45}$ Wawancara, 17 September 2017.

${ }^{46}$ M. Quraish Shihab, Lentera Hati, Kisah dan Hikmah Kehidupan (Bandung: Mizan, 1994), 98.

${ }^{47}$ Ahmad bin Fâris, Mu'jam al-Maqâyîs fî al-Lughah (Beirut: Dâr al-Fikr, 1994), 802.

${ }^{48} \mathrm{M}$. Quraish Shihab, Lentera... 99. 
Jamaah Tabligh berpandangan bahwa penafian materi, bukan berarti harus membenci, menjauhi, dan menghalaunya. Manusia sebagai makhluk yang memiliki unsure materi (biologis) tidak dapat lepas dari dunia materi. Akan tetapi materi tidak dijadikan tujuan utama. Materi tidak dikukuhkan sebagai sesuatu yang harus ditetapkan. Dengan demikian, maka manusia tetap menjadi pengendali materi, bukan dikendalikan materi. ${ }^{49}$

Kesadaran terhadap keberadaan dan posisi materi dalam kehidupan, menumbuhkan kesadaran dalam berikhtiyar. Dalam hal ini maka kehidupan tidak dapat dipisahkan dengan ikhtiyar. Sebagaimana juga ikhtiyar tidak dapat dipisahkan dengan keyakinan akan kekuasaan Allah. Ikhtiyar adalah bagian ibadah sosial. Jika ibadah mahdlah tempat dan caranya telah ditetapkan sedemikian rupa yang tidak menerima kreativitas dari manusia, maka ibadah sosial tempatnya bersifat umum. Waktu dan tata caranya sangat kondisional seiring dengan nafas kehidupan. Dalam hal ini, upaya pencarian hidup yang tujuannya untuk dakwah, adalah bagian dari ibadah..$^{50}$

\section{Konsep Tawakkal dalam Kehidupan}

\section{Makna Tawakkal}

Menurut bahasa Indonesia, kata tawakal berarti pasrah diri kepada kehendak Allah setelah berusaha untuk mencapai apa yang diharapkan. ${ }^{51}$ Rangkaian definisi tersebut memberikan konteks makna bahwa ketika manusia berserah atau pasrah lebih dahulu diawali sebuah usaha. Setelah menjalani usaha dan ternyata belum mencapai apa yang diharapkan, maka manusia merasa dan menyadari kelemahan dan kekurangan yang akhirnya menyerahkan kepada Dzat yang dianggap memiliki kekuasaan. Sementara dalam bahasa Arab, kata tawakkal berasal dari kata wakala-yakilu, yang berarti menyerahkan urusan kepada pihak lain untuk bertindak seperti apa yang dikehendaki oleh yang menyerahkan. ${ }^{52}$ Sebagaimana dalam istilah Indonesia, istilah Arab pun memberikan konteks makna kata

\footnotetext{
${ }^{49}$ Wawancara, 17 September 2017.

${ }^{50}$ Wawancara, 17 September 2017.

${ }^{51}$ Pusat Bahasa Departemen Pendidikan Nasional, Kamus Besar Bahasa Indonesia (Jakarta: Balai Pustaka, 2003), 1150.

${ }^{52}$ Ahmad bin Fâris, Mu’jam al-Maqâyîs fî al-Lughah (Beirut: Dâr al-Fikr, 1994), 1102.
} 
tersebut yaitu adanya rasa kekurangan dan keterbatasan bagi yang mewakilkan, sehingga meminta pihak lain untuk bertindak seperti yang diinginkan. Dalam bahasa Indonesia hal tersebut lazim disebut mewakilkan.

Dari definisi kebahasaan, kata wakîl yang menunjuk pada pengganti, akan lebih cocok jika dikontekskan dengan sesame makhluk. Orang yang ditunjuk untuk mewakili, maka orang tersebut tidak akan berbuat melebihi dari wewenang yang diberikan kepadanya. Sehingga orang yang telah mewakilkan dia telah bebas tari tagihan karena sudah diwakilkan, dan orang yang mewakili dia tidak akan bertindak melebihi dari apa yang diwakilan. Akan tetapi jika kata wakîl dalam ayat di atas dikaitkan dengan Allah, maka tidak lazim yang mewakilkan membatasi kewenangan Dia terhadap manusia. Oleh karenanya, kata tersebut tidak sekadar pengganti, tetapi juga pelindang. ${ }^{53}$

Ketika manusia menyerahkan segala urusan kepada Allah, terlebih dahulu manusia menyadari akan keterbatasannya. Kesadaran akan kekurangan dan keterbatasan ini yang menjadi kata kunci makna kata wakîl. Menjadikan Allah sebagai wakîl adalah menyerahkan apa yang ada yang telah dilakukan sembari diikuti dengan kesadaran akan kelemahan dan kekurangan terhadap apa yang telah dia upayakan.

\section{Tawakkal Indikator Keimanan}

Al-Qur'an memberikan isyarat bahwa di antara ciri orang yang beriman, setelah dia bertaqwa, maka dia selalu bertawakkal seperti dalam al-Mâ'idah/5:11. Dalam ayat ini, kata tawakkal lebih dahulu diawali dengan kata imân, kata dzikr, dan kata taqwâ. Ini memberikan isyarat bahwa tawakkal bukanlah keputusan yang diambil di awal pekerjaan. Sebelum bertawakkal, maka orang harus yakin dulu dengan apa yang ia kerjakan sesuai dengan yang hasilnya akan sesuai dengan kadar dan kemampuannya (îmân). Setelah itu manusia harus senantiasa sadar bahwa ketika dia sedang melakukan sesuatu untuk mewujudkan impian dan harapannya, akan mungkin terjadi sesuatu yang di luar yang dia bayangkan (dzikr). Kemudian setelah itu manusia harus selalu berusaha untuk melakukan semua

${ }^{53}$ M. Quraish Shihab, Secerah Cahaya Ilahi (Bandung: Mizan, 2013), 171.

Kodifikasia, Volume 11 No. 1 Tahun 2017 
sebab yang dipandang sebagai wasilah untuk mencapai apa yang diharapkan, sembari menjauhkan semua sebab yang diprediksikan akan menghalangi tujuannya (taqwâ). Baru setelah itu menyerahkan apa yang telah dia lakukan sesuai dengan prosedur dan langkah langkah (tawakkal). ${ }^{54}$

Menurut Jamaah Tabligh, usaha dan tawakkal merupakan suatu kesatuan proses yang tidak dapat dipisahkan. Allah memerintahkan kepada manusia untuk mengambil hukum sebab untuk mecapai akibat yang diharapkan. Akibat apa pun yang akan diterima manusia, maka ia harus dapat menerimanya. Karena dibalik apa yang diketahui dan dikuasai oleh manusia, ada hukum lain yang tidak diketahui oleh manusia dan tidak dikuasai oleh manusia. Di saat inilah manusia berkelaziman untuk menyerahkan semua yang telah dia upayakan. ${ }^{55}$

Seberapa kesadaran manusia terhadap kekurangan dan kelemahannya, maka sebesar dan sekuat itu pula mestinya tawakkal manusia kepada Allah. Pengingkaran salah satu sisi baik usaha atau tawakkal merupakan sikap yang tidak etis dan tidak tahu diri pisisi makhluk terhadap sang khaliqnya. Mengingkari ikhtiyar berarti sama halnya mengkufuri pemberian Allah pada diri manusia. Mulai dari akal, indera dan berbagai pemberian Allah yang mestinya mampu diupayakan untuk mengupayakan nikmat dan pemberian Allah. Sebaliknya, pengingkaran terhadap tawakkal merupakan sikap kufur dan sombong sebagai makhluk terhadap kekuasaan ilahinya. ${ }^{56}$

\section{Akulturasi Budaya Dan Ajaran}

\section{Akulturasi Budaya Menuju Nilai Ekonomi}

Menurut teori sosial, bahwa kehidupan ekonomi masyarakat, biasanya disebabkan oleh keterbukaan masyarakat. Artinya, masyarakat tersebut terjadi perubahan dan akulturasi, baik budaya maupun peradaba. Secara otomatis telah terjadi mobilisasi sosial, baik itu bersifat urban maupun migrasi. ${ }^{57}$ Akulturasi adalah suatu proses sosial yang timbul manakala suatu kelompok manusia dengan kebudayaan tertentu dihadapkan dengan unsur dari suatu

\footnotetext{
${ }^{54}$ Waryono Abdul Ghafur, Tafsir Sosial (Yogyakarta: eLSAQ Press, 2005), 31.

${ }^{55}$ Wawancara, 17 September 2017.

${ }^{56}$ Wawancara, 17 September 2017.

${ }^{57}$ Talcott Parsons, dalam Peter Beilharz, Teori Teori Sosial, Terj. Sigit Jatmiko (Yogyakarta: Pustaka Pelajar, 2003), 292.
} 
kebudayaan asing. Kebudayaan asing itu lambat laun diterima dan diolah ke dalam kebudayaannya sendiri tanpa menyebabkan hilangnya unsur kebudayaan kelompok itu sendiri..$^{58}$ Akulturasi budaya terjadi karena perpaduan antara kebudayaan yang berbeda yang berlangsung dengan damai dan serasi. ${ }^{59}$

Ponodok Al-Fatah yang berdiri lebih awal dari kedatangan Jamaah Tabligh, merupakan ikon yang menjadi daya tarik kedua unsur. Unsur masyarakat lokal sebagai khazanah budaza lokalnya, Jamaah Tabligh sebagai mitra untuk mengembangkan dakwah dan ajarannya. Dalam hal ini, kedua unsur ini tidak dapat disisihkan satu sama lain. Keduanya saling berinteraksi aktif. Masyarakat Temboro dengan pondoknya yang telah merubah sekaligus memberi warna spiritual masyarakat, menerima kehadiran pihak lain yang senafas dengan visi dan misi pondok. Dalam waktu yang sama, Jamaah Tabligh dengan konsep ajarannya, merasa mendapat tempat sekaligus mitra untuk mengembangkan visi dan misi ajarannya. Dengan demikian, kedua belah pihak merasa saling menguntungkan dan diuntungkan.

Dari kondisi tersebut, antara masyarakat Temboro dengan modal pondok yang ada, dan Jamaah Tabligh dengan konsep ajaran yang dibawanya, dapat menyatu dan melebur menjadi satu membentuk kultur baru dalam masyarakat. Keduanya merasa saling diuntungkan, dan keduanya saling memberikan interaksi positif kepada pihak lain. ${ }^{60}$

\section{Akulturasi Budaya Menuju Harmonisasi}

Tidak banyak terjadi, proses akulturasi budaya yang saling mendukung. Kultur yang berasal dari satu komunitas, menjadi nafas dan spirit bagi kultur dan komunitas yang lain. Hal ini terjadi jira hal yang menjadi patri merupakan kebutuhan bagi kedua belah pihak. Pondok dengan visinya untuk menanamkan spitual lepada ummat, dan Jamaah Tabligh dengan vsisinya untuk metrubah dan mengajak ummat ke jalan agama, menjadi patri yang kokoh terjadinya akulturasi dari kedua budaya yang mungkin asalnya berbeda.

\footnotetext{
${ }^{58}$ https://id.wikipedia.org/wiki/Akulturasi. Diakses tanggal: 10 September 2017, pk. 20.00 .

${ }^{59} \mathrm{http}: / /$ rakaestu.blogspot.co.id/2012/03/pengertian-akulturasi-kebudayaan.html. Diakses tanggal: 10 September 2017, pk. 20.00.

${ }^{60}$ Wawancara, 17 September 2017.
} 
Kultur baru yang hidup dan berkembang di desa Temboro saat ini, didukung oleh kedua unsur, yaitu unsur awal kearifan lokal yang ditanamkan oleh pesantren al-Fatah. Dan unsur pendatang yang dibawa oleh Jamaah Tabligh. Kultur tersebut tidak sekadar konsep ajaran, tetapi juga budaya. Seperti berbakaian, keramahan, paham keagamaan dan kultur kemajemukan yang bhinnekais dan multikulturalis. ${ }^{61}$

\section{Faktor Pendorong Usaha dan Keharmonian}

Hal penting yang mengharmonikan akulturasi antara budaya lokal dan kultur baru adalah konsep ajaran yang ditawarkan oleh kultur baru dan diterima oleh kultur lokal. Dampak dari akulturasi budaya menghasilkan keharmonian, sekalgus sebagai faktor yang membentuk karakter dan etos kerja bagi Jamaah Tabligh Temboro. Di antaranya: a. Konsep ajaran Jamaah Tabligh mendorong untuk berusaha dan bekerja.

Konsep enam sifat shahabat yang dijadikan prinsip kehidupan dan beragama Jamaah Tabligh, memegang peran penting untuk mendorong etos kerja Jamaah Tabligh. Penafian materi, tidak dikehendaki untuk menjahui apa lagi membenci kehidupan materi. Hanya saja prinsip ini sebagai pengendali agar dalam bekerja bukan semata mata untuk mencari materi. Akan tetapi untuk mencari fadilah dari materi yang dapat dilakukan untuk melakukan kebajikan dalam kehidupan.

Pengitsbatan Allah dengan segala kekuasaannya, menjadikan Jamaah Tabligh yakin bahwa usaha yang didasarkan pada keyakinan akan kekuasaan Allah akan sukses. Kondisi ini membentuk mental optimis dalam melakukan usaha. Ajaran ikrâm al-Muslimin, mendorong anggota Jamaah Tabligh untuk berlomba lomba menolong saudaranya membutuhkan. Dengan akal yang logis, agar dapat menjalankan konsep dan prinsip ini, maka yang bersangkutan harus bekerja keras untuk mendapatkan materi sehingga ia dapat melaksanakan konsep ajaran tersebut.

Konsep dan ajaran Tabligh, yang mengharuskan bagi anggota Jamaah untuk khurûj dalam limit waktu yang dipilihnya. Aktivitas ini dilakukan secara mandiri bagi tiap tiap anggota tanpa adanya

${ }^{61}$ Ibid. 
ketergantungan dari pihak lain. Kegiatan tersebut membutuhkan dana dan modal untuk bekal selama dalam proses. Tidak sekedar kepentingan yang bersangkutan, tetapi juga untuk bekal keluarga yang ditinggalkan. Hal ini karena Jamaah Tabligh tidak boleh ikut program khurûj, kecuali setelah menunjukkan kesiapan baik mental maupun material. Jika tidak demikian, maka keberadaannya hanya akan mengganggu pihak lain. Dalam waktu yang sama, tidak akan dapat menjalankan prinsip memperbaiki niat atau hati (tahsin al-niyyah).

b. Keterbukaan Masyarakat Untuk Berinteraksi.

Salah satu konsep ajaran yang disampaikan dan dipraktikkan oleh Jamaah Tabligh adalah silaturrahmi. Bahkan ketika sampai di lokasi dakwah, hal awal yang harus dilakukan adalah bersilaturrahmi kepada para tokoh dan masyarakat sekitar. Dari ajaran ini ini, akhirnya membentuk kultur yang harmoni dan bermartabat. Akhirnya desa Temboro menjadi masyarakat yang terbuka untuk migrasi dan urban.

Datangnya para tamu dan santri yang tujuan awalnya adalah untuk belajar di desa Temboro, ditangkap oleh masyarakat Temboro sebagai suatu potensi dan kesempatan untuk berkarya dalam mencari kehidupan. Dalam hal ini, maka sikap masyarakat Temboro terhadap tamu dianggap sebagai barakah yang datang kepada mereka. Mereka memanfaatkan tamu tersebut untuk ber-ikrâm kepada mereka dengan menyediakan berbagai kebutuhan dan hajat kehidupannya.

c. Konsep Ketaatan Terhadap Ajaran agama

Kesan awal yang dapat ditangkap oleh masyarakat dari kekhususan ajaran gama yang disampaikan oleh Jamaah Tabligh adalah ketaatan kepada ajaran agama. Konsep ini merupakan buah dari metode dan materi ajaran agama yang mereka terima yaitu masalah fadlail alA'mâl. Konsep fadlail al-A'mâl mampu untuk menumbuhkan etos dan mental bagi yang bersangkutan. Dalam menjalankan sesuatu, mereka tidak merasa adanya tekanan dan kekangan. Tetapi didorong atas kesadaran terhadap sesuatu yang menggembirakan.

Berangkat dari ketaatan terhadap ajaran agama, membuahkan etos kerja yang dinamis. Mereka kerja bebas dari tipu menipu. Bebas dari unsure ribawi dan hegemoni. Mereka bekerja didasarkan pada keterpanggilan nurani dan ketulusan niyat. Akhirnya menjadikan konsumen merasa terlayani dengan baik, dan merasa adanya keberkahan. Walhasil, nafas ekonomi akhirnya menggeliyat. 


\section{PENUTUP}

Menurut Jamaah Tabligh, kerja adalah upaya untuk mendapatkan jaminan Allah untuk kehidupan melalui pemanfaatan potensi yang ada pada manusia. Hanya saja kerja bukan semata mata bertujuan untuk mengejar materi, tetapi untuk mencari ridla ilahi. Karena kehidupan materi telah ditetapkan oleh Allah. Berdasarkan keyakinan kalimat thayyibah, Jamaah Tabligh memandang bahwa ikhtiyar harus dilakukan sebelum bertawakkal. Mengingkari ikhtiyar berarti mengingkari akan kebutuhan hajat hidup. Materi sebagai hajat hidup, bukan tujuan hakiki dalam kehidupan, tetapi sebagai wasilah untuk mencapai tujuan yang sesungguhnya. Tawakkal bukan sekadar menerima kegagalan, tetapi menyerahkan semua yang terjadi dalam kehidupan. Konsep ajaran ikrâm al-Muslimîn, dan tahsîn al-Niyyat, menjadikan Jamah Tabligh dapat menerima pihak lain. Iklim keharmonian dalam kehidupan, menciptakan etos untuk memanfaatkan moimentum keterbukaan kehidupan dalam bermasyarakat dengan menyediakan berbagai jasa dan kebutuhan kehidupan. Akhirnya berdampak pada kesejahteraan yang dilingkupi rasa aman, nyaman dalam suasana religius.

\section{DAFTAR RUJUKAN}

Al-Kandahlawy, Zakariya, Otobiografi Kisah-Kisah Kehidupan Syaikhul Hadits Maulana Zakariyya al- Kandhalawi, Terj. Abd Rahman Ahmad as-Sirbuny, Cirebon: Pustaka Nabawi, 2009.

Al-Rosyid, Mulwi Ahmad Harun, Meluruskan Kesalahpahaman terhadap Jaulah (Jamaah Tabligh), Magetan: Pustaka Haromain, 2004.

An Nadhr M. Ishaq Shahab, Khuruj fisabilillah: Sarana Tarbiyah Untuk Membentuk Sifat Imaniyah, terj. Abu Sayyid Akmal Bandung: Pustaka Zâdul Ma'âd. 
An-Nadwi, Abul Hasan, Sejarah Dakwah dan Tabligh Maulana Muhammad Ilyas Rah Bandung: Al Hasyimiy, 2009.

Anshari, Furqon Ahmad, Pedoman BerTabligh Bagi Umat Islam Jogjakarta: Ash-Shaff, 2013.

As-Sirbuny, Abdurrahman Ahmad, Mudzakarah Masturat, Cirebon: Pustaka Nabawi, 2009.

Boisard, Marcel A., Humanisme Dalam Islam, Terj. M. Rasjidi, Jakarta: Bulan Bintang, 1980.

Darussalam dkk, Model Dakwah Jama'ah Tabligh, Salatiga: STAIN Salatiga Press, 2011.

Fakhri, Madjid, Etika Dalam Islam, Terj. Zakiyuddin Baidhawy, Yogyakarta: Pustaka Pelajar, 1996.

Fâris, Ahmad bin, Mu'jam al-Maqâyîs fî al-Lughah, Beirut: Dâr alFikr, 1994.

Fromm, Erich, Konsep Manusia Menurut Marx, Yogyakarta: Pustaka Pelajar, 2002.

Ghafur, Waryono Abdul, Tafsir Sosial, Yogyakarta: eLSAQ Press, 2005.

Jabir, Ali, Membentuk Jama'atul Muslimin, Jakarta: Gema Insani Press, 1998.

Kandhalawi, Maulana Yusuf al-, Enam Sifat Para Sahabat dan Amalan Nurani, Bandung: Pustaka Ramadhan, 2008.

Manshur, Maulana, Keutamaan Masturah; Usaha Dakwah di Kalangan Wanita Bandung: Pustaka Ramadhan, 2010.

Nadwi, Ali, Riwayat Hidup dan Usaha Dakwah Maulana M. Ilyas, terj: Masrokhan A, Yogyakarta: Ash-Shaff, 1999.

Parsons, Talcott, dalam Peter Beilharz, Teori Teori Sosial, Terj. Sigit Jatmiko, Yogyakarta: Pustaka Pelajar, 2003.

Pusat Bahasa Departemen Pendidikan Nasional, Kamus Besar Bahasa Indonesia, Jakarta: Balai Pustaka, 2003.

Rachman, Budhy Munawar, (ed), Kontekstualisasi Doktrin Islam Dalam Sejarah, Jakarta: Paramadina, 1995. 
Ridlâ, Muhammad Rasyîd, Tafsîr al-Qur'ân al-Hakîm Beirût: Dâr alMa'rifah, tt.

Rusyd, Ibn, Bidâyah al-Mujahid wa Nihâyah al-Muqtashid Beirût: Dâr al-Fikr, 1982.

Sayani, Mustofa, Mudzakarah Enam Sifat Para Sahabat RA. Bandung: Pustaka, 2006.

Shihab, M. Quraish, Lentera Hati, Kisah dan Hikmah Kehidupan, Bandung: Mizan, 1994.

.......-, Membumikan al-Qur'an Bandung: Mizan, 1996.

.......-, Secerah Cahaya Ilahi, Bandung: Mizan, 2013.

........, Wawasan al-Qur'an, Bandung: Mizan, 1999.

Suseno, Franz Magnis, Pemikiran Karl Marx Dari Sosialisme Utopis ke Perselisihan Revisionisme Jakarta: Gramedia, 1999.

Suyûthî, Jalâl al-Dîn al-, Al-Itqân fî 'Ulûm al-Qur'ân Beirut: Dâr alQalam, tt. 
